\title{
The modern "3G" age of archaeal molecular biology
}

\author{
Frank T. Robb ${ }^{1,2}$, Todd M. Lowe ${ }^{3}$ and Zvi Kelman ${ }^{4,5 *}$ \\ 1 Institute of Marine and Environmental Technology, Baltimore, MD, USA \\ 2 University of Maryland School of Medicine, Baltimore, MD, USA \\ ${ }^{3}$ Department of Biomolecular Engineering, University of California, Santa Cruz, CA, USA \\ ${ }^{4}$ National Institute of Standards and Technology, Gaithersburg, MD, USA \\ ${ }^{5}$ Institute for Bioscience and Biotechnology Research, Rockville, MD, USA \\ *Correspondence: zkelman@umd.edu
}

Edited by:

John R. Battista, Louisiana State University and A \& M College, USA

Reviewed by:

John R. Battista, Louisiana State University and A \& M College, USA

The publication of the genome of Methanocaldococcus jannaschii in 1996 (Bult et al., 1996), just the second-ever complete microbial sequencing feat, marked an exciting beginning for archaeal genomics. In spite of the auspicious start, progress in archaeal genomics has been slow relative to bacteria and viruses, in part due to sequencing funding priorities favoring microbes with clinical relevance. In the last 5 years, the precipitous drop in high throughput sequencing costs and increasingly automated genome annotation has caused the inventory of archaeal genomes to grow exponentially. There is now genome representation in all major phyla of the Archaea, with a number of popular genera (including Halobacterium, Methanocaldococcus, Methanosarcina, Pyrobaculum, Pyrococcus, Sulfolobus, and Thermococcus) represented by multiple species. With these sequence data, comparative genomic studies have played an important role in integrating a broader evolutionary perspective into archaeal research. Experimental genetics now commonly utilize multiple archaeal species in a modern systems approach, coinciding with an increasing upswing in international collaboration. Multilaboratory consortia, such as the SulfoSys community (Albers et al., 2009), have started to break into new systems biology initiatives. At the same time, streamlined genetic approaches in the genera Halobacterium/Haloferax, Methanosarcina, Sulfolobus, and Thermococcus, are leveraging

\section{REFERENCES}

Albers, S. V., Birkeland, N. K., Driessen, A. J., Gertig, S., Haferkamp, P., Klenk, H. P., et al. (2009). SulfoSYS (Sulfolobus Systems Biology): towards a silicon cell model for the central carbohydrate metabolism of the archaeon Sulfolobus solfataricus under temperature variation. Biochem. Soc. Trans. 37, 58-64.

Atomi, H., Imanaka, T., and Fukui, T. (2012). Overview of the genetic tools in the Archaea. Front. Microbio. 3:337. doi: 10.3389/fmicb. 2012.00337
Bernick, D. L., Cox, C. L., Dennis, P. P., and Lowe, T. M. (2012a). Comparative genomic and transcriptional analyses of CRISPR systems across the genus Pyrobaculum. Front. Microbio. 3:251. doi: 10.3389/fmicb.2012. 00251

Bernick, D. L., Dennis, P. P., Lui, L. M., and Lowe, T. M. (2012b). Diversity of antisense and other non-coding RNAs in archaea revealed by comparative small RNA sequencing in four Pyrobaculum species. Front. Microbio. 3:231. doi: 10.3389/fmicb.2012.00231

the growing wealth of genomic information in the Archaea. The result has been genome-driven studies of metabolism, DNA replication and repair, transcription and translation, and posttranslational processing.

This collection of 11 papers attempts to put this quiet maturation in archaeal molecular biology in context with a mix of overview articles (Atomi et al., 2012; Hileman and Santangelo, 2012; Kohler and Metcalf, 2012; Wagner et al., 2012) and original data (Bernick et al., 2012a,b; Iverson and Stedman, 2012; Mao and Grogan, 2012; Schut et al., 2012; Stroud et al., 2012; Szabo and Pohlschroder, 2012) highlighting the expansion of important areas enabled by the 3G's: genomics, genetics, and global collaboration. Research papers highlight the roles of small RNAs, CRISPR action, mechanisms of membrane secretion, hydrogen production, and DNA replication, while excellent technical overviews cover recently developed genetic methods within four major research communities utilizing Haloferax, Sulfolobus, Pyrococcus, or Thermococcus.

\section{ACKNOWLEDGMENTS}

The support of Air Force Office of Scientific Research Grant AFOSR FA9550-10-1-0272 to Frank T. Robb is gratefully acknowledged.

Bult, C. J., White, O., Olsen, G. J., Zhou, L., Fleischmann, R. D., Sutton, G. G., et al. (1996). Complete genome sequence of the methanogenic archaeon, Methanococcus jannaschii. Science 273, 1058-1073.

Hileman, T. H., and Santangelo, T. J. (2012). Genetics techniques for Thermococcus kodakarensis. Front. Microbio. 3:195. doi: 10.3389/fmicb. 2012.00195

Iverson, E., and Stedman, K. (2012). A genetic study of SSV1, the prototypical fusellovirus. Front. Microbio. 3:200. doi: 10.3389/fmicb. 2012.00200
Kohler, P. R. A., and Metcalf, W. W. (2012). Genetic manipulation of Methanosarcina spp. Front. Microbio. 3:259. doi: 10.3389/fmicb. 2012.00259

Mao, D., and Grogan, D. W. (2012). Heteroduplex formation, mismatch resolution, and genetic sectoring during homologous recombination in the hyperthermophilic archaeon Sulfolobus acidocaldarius. Front. Microbio. 3:192. doi: 10.3389/fmicb.2012.00192

Schut, G. J., Nixon, W. J., Lipscomb, G. L., Scott, R. A., and Adams, M. W. W. 
(2012). Mutational analyses of the enzymes involved in the metabolism of hydrogen by the hyperthermophilic archaeon Pyrococcus furiosus. Front. Microbio. 3:163. doi: 10.3389/fmicb.2012. 00163

Stroud, A., Liddell, S., and Allers, T. (2012). Genetic and biochemical identification of a novel single-stranded DNAbinding complex in Haloferax volcanii. Front. Microbio.
3:224. doi: 10.3389/fmicb.2012. 00224

Szabo, Z., and Pohlschroder, M. (2012) Diversity and subcellular distribution of archaeal secreted proteins. Front. Microbio. 3:207. doi: 10.3389/fmicb.2012. 00207

Wagner, M., van Wolferen, M., Wagner, A., Lassak, K., Meyer, B. H., Reimann, J., et al. (2012). Versatile genetic tool box for the crenarchaeote Sulfolobus acidocaldarius. Front. Microbio. 3:214. doi: 10.3389/fmicb.2012 00214

Received: 12 November 2012; accepted: 06 December 2012; published online: 20 December 2012

Citation: Robb FT, Lowe TM and Kelman Z (2012) The modern " $3 G$ " age of archaeal molecular biology. Front. Microbio. 3:430. doi: 10.3389/fmicb. 2012.00430
This article was submitted to Frontiers in Evolutionary and Genomic Microbiology, a specialty of Frontiers in Microbiology.

Copyright (c) 2012 Robb, Lowe and Kelman. This is an open-access article distributed under the terms of the Creative Commons Attribution License, which permits use, distribution and reproduction in other forums, provided the original authors and source are credited and subject to any copyright notices concerning any third-party graphics etc. 